\title{
Polyphenol-rich extract of Ocimum gratissimum leaves prevented toxic effects of cyclophosphamide on the kidney function of Wistar rats
}

\author{
Quadri K. Alabi ${ }^{*}$, Rufus O. Akomolafe ${ }^{2}$, Joseph G. Omole ${ }^{2}$, Ayodeji Aturamu ${ }^{3}$, Mokolade S. Ige ${ }^{4}$, \\ Oyindasola O. Kayode ${ }^{5}$ and Deborah Kajewole-Alabi ${ }^{6}$
}

\begin{abstract}
Background: Cyclophosphamide (CP) is one of the potent and low cost chemotherapy used in clinical setting against a variety of tumors. However, its association with nephrotoxicity limits its therapeutic use. Ocimum gratissimum leaf is a medicinal plant with numerous pharmacological and therapeutic efficacies, such as antioxidant, antiinflammation, and anti-apoptotic properties.
\end{abstract}

Methods: The present study was designed to evaluate the protective effect of Ocimum gratissimum (OG) against CPinduced kidney dysfunction in rats. Rats were pre-treated with $400 \mathrm{mg} / \mathrm{kg}$ b.w. of leave extract of Ocimum gratissimum (Ocimum G.) for 4 days and then $50 \mathrm{mg} / \mathrm{kg}$ b.w. of CP was co-administered from day 5 to day 7 along with Ocimum $\mathrm{G}$. Markers of renal function and oxidative stress, food and water intake, electrolytes, aldosterone, leukocytes infiltration, inflammation and histopathological alteration were evaluated.

Results: Obvious renal inflammation and kidney injuries were observed in CP treated groups. However, administration of leave extract of Ocimum G. prevented oxidative stress, kidney injuries, attenuated inflammation, increased aldosterone production and reduced sodium ion and water loss in rats. The plasma creatinine, urea and urine albumin concentration were normalized after the administration of Ocimum G. extract in rats treated with CP. Ocimum G. also decreased the plasma concentrations of Interleukin-(IL)-6, C-reactive protein and activity of myeloperoxidase and malondialdehyde in CP treated rats.

Conclusion: Ocimum G. prevented kidney injury and enhanced renal function via inhibiting inflammation and oxidant-induced CP toxicity. The efficacy of Ocimum G. is related to the presence of various phytochemicals in the plant.

Keywords: Antioxidant, Creatinine, Cyclophosphamid, Ocimum gratissimum leaf, Kidney, Sodium

*Correspondence: alabikunlequadri@gmail.com; alabi. quadri@adelekeuniversity.edu.ng

${ }^{1}$ Department of Physiology, Faculty of Basic Medical Sciences, Adeleke University, Ede, Osun State, Nigeria

Full list of author information is available at the end of the article

\section{Background}

Cyclophosphamide (CP) is an antineoplastic compound that is associated with nitrogen mustard. It is used in the clinical setting to treat a wide variety of cancer diseases and in immunosuppressive therapy after organ transplants, treatment for autoimmune disorders such as rheumatoid arthritis, Wegener's granulomatosis, and nephritic syndrome in children [1]. Regardless of the 
wide spectrum of clinical uses of the drug, CP is known to cause numerous dose-dependent organ injuries, which, therefore, restraining its therapeutic use in the clinical setting. As it was known to be beneficial in the treatment of nephritic syndrome in children [1], it was conversely reported in some previous studies to induce urinary bladder damage $[2,3]$ and cause renal toxicity when used inappropriately owing to the use of $\mathrm{CP}$ overdose [4-6].

The CP active metabolite, 4-Hydroxycyclophosphamide, is partially tautomerized into aldosphosphamide, which in turn is broken down by phosphatase in the circulation and live cell and give rise to two cytotoxic metabolites, phosphoramide mustard and acrolein [6]. The therapeutic action of phosphoramide mustard has been previously reported to be responsible for antitumor effects [6], while acrolein is responsible for cytotoxic effects of $\mathrm{CP}$, such as hemorrhagic cystitis during the drug administration [2, 7]. The CP toxic metabolite damages the living tissues by abating the tissue endogenous antioxidant system through the generation of reactive oxygen free radicals which are mutagenic to living cells.

Administration of high dose of CP has been reported to increase lipid peroxidation and causes reduction in the endogenous enzymatic and non-enzymatic antioxidants $[7,8]$. Previous studies have described the beneficial uses of antioxidants substances along with chemotherapy in preventing the drugs side effect on the body tissues [7, $9,10]$. The antioxidant agent like kolaviron proved effective in the prevention of CP cardiotoxicity in rats [11]. Thus, the combination of the antioxidant agent along with chemotherapy drugs may be a potential therapeutic approach to prevent or stop the cytotoxic development of CP.

Ocimum gratissimum (Ocimum G.) is a family of Lamiaceae which belong to herbaceous plant species. It is known as clove or African basil in many tropical areas countries (Asia, India, Brazil and West Africa etc). It is vastly found in Nigeria [12]. Many states of this country (Nigeria) used Ocimum G. as a sauce and vegetable soup. The leaves and flowers of Ocimum G. have been found to possess polyphenols and other bioactive compounds [13, 14]. Ocimum gratissimum plants are used to treat various illnesses like diarrhea, ulcerative colitis, fever, and catarrh [14-17]. The plant has many pharmacological advantages due to its anti-inflammatory, anti-oxidative, antibacterial, antidiabetic and antimalarial capabilities [14, 18-20]. The anti-microbial activity of the Ocimum G. extract has been tested in vitro against various human pathogens like Klebsiella pneumoniae, Staphylococcus aureus, Escherichia, Vibro spp, Enterobacter spp, Enterococcus faecalis, etc. The antifungal activity of the essential oil of
Ocimum G. extracts has been noted in vitro [19, 21, 22], and Ocimum G. has been used as a mosquito appellant [23]. A recent animal study suggested the importance or protective effect of Ocimum G. extracts in the prevention of blood pressure irregularities against cobalt-chloride toxicity [24] as well as attenuating cardiac abnormalities associated with liver fibrosis by downregulating the interleukin-6 signaling pathway [25] or by inducing antioxidant effects [26]. Aqueous leave extract of Ocimum G. leaves showed antioxidant effect against cobalt chlorideinduced cardio-renal injury [24] and prevented gastric ulcers by reducing gastric acid secretion and ulceration [27]. Also, urosolic acid from Ocimum G. extracts demonstrated anti-sickling activity [28] and anticancer [29, 30]. Furthermore, the essential oils of Ocimum G. have been shown to exhibit endothelium-dependent, vasorelaxant properties in rats [31]. In vivo and in vitro studies have evaluated eugenol, a medicinal constituent of Ocimum G., to lower blood glucose levels via inhibition of alpha-glucosidase [32]. More so, a clinical study established the pharmacological adequacy of Ocimum G. to exhibit similar activity as chlorhexidine against plaque and gingivitis [33]. With all these features of Ocimum G., we hypothesized that Ocimum G. might be a possible therapeutic when use along with $\mathrm{CP}$ to prevent or stop $\mathrm{CP}$ adverse effect. This study was therefore designed to examine the beneficial effects of polyphenol rich extract of Ocimum gratissimum leaves on CP-induced nephrotoxicity in male Wistar rats.

\section{Materials and methods}

\section{Drugs, chemicals and instruments}

Cyclophosphamide $(200 \mathrm{mg} / 10 \mathrm{~mL})$ injection was procured from Celon Laboratory (Hyderabad, India); ketamine hydrochloride $(50 \mathrm{mg} / 10 \mathrm{~mL})$ injection was purchased from Popular Pharmaceuticals Ltd., (Gazipur, Bangladesh); Assay kits for biochemical parameters were obtained from Randox Laboratories Limited, (Crumlin, UK) etc. 1-diphenyl-2-picrylhydrazyl (DPPH), methanol, sodium carbonate, trolox, and Folin-Ciocâlteu reagent were purchased from Merck \& Co., Kenilworth, NJ, USA. The instruments used include the gas chromatography-mass spectrometer (GCMS-QP2010 SE, Shimadzu Corporation, Kyoto, Japan), an ultraviolet-visible spectrophotometer (Beckman, DU 7400, USA), Soxhlet apparatus, rotary evaporator, microscope (Olympus $\mathrm{CH}$; Olympus, Tokyo, Japan); camera (Leica DM 750).

\section{Preparation of polyphenol extract of Ocimum gratissimum leaves}

The Ocimum gratissimum leaves were collected from a garden at Usi, Ekiti state, Nigeria. Relevant institutional permissions to collect Ocimum gratissimum were 
obtained. The present study complies with the international, national and/or institutional guidelines for the use of different parts of the plant. The specimens of the plant were authenticated by Mr. Omole, the curator at the herbarium of Botany Department, Obafemi Awolowo University, Ile-Ife, where a voucher specimen (1945) was deposited in the Herbarium of the University. The polyphenol rich extract was obtained from the Ocimum G. leaves $(900 \mathrm{~g})$ according to our previous extraction methods of the plant [14]. Methanol was used to obtained the final extraction product, polyphenol rich extract of Ocimum gratissimum (PREOG) leaves under reduced pressure at $40^{\circ} \mathrm{C}$ using a rotary evaporator. The resulting extract concentrate was freeze dried with the aid of a lyophilizer. The residue $(80.85 \mathrm{~g})$ was kept in petri dishes with a tight fitting cover and stored at $-20^{\circ} \mathrm{C}$ until it was needed for the study.

$$
\begin{gathered}
\text { Extraction yield in } \%=80.85 / 900 * 100 \\
=8.98 \% .
\end{gathered}
$$

The OG extract obtained was dissolved in water $(0.2 \mathrm{~mL} /$ administration $)$ and given to rat according to the designed dosage.

\section{Gas chromatography-mass spectrometry analysis of (GC-MS) OG extracts}

The chemical composition of the extract obtained was checked using gas chromatography-mass spectrometry (GC-MS). Kavaz et al. [34] method was adopted with slight modification. A fused-silica capillary column (film thickness of $30 \times 0.25 \mathrm{HP}-5 \mathrm{Ms}, 0.25 \mu \mathrm{m}$ ) containing helium as the carrier gas $(1 / \mathrm{mL}$ flow rate) was used for the determination of the compounds. $40^{\circ} \mathrm{C}$ oven temperature was set and held for $5 \mathrm{~min}$, and then augmented gradually by $3^{\circ} \mathrm{C} / \mathrm{min}$ up to $270^{\circ} \mathrm{C}$. $60: 1$ was set as split ratio. Temperature of $180^{\circ} \mathrm{C}$ was set for the connection parts and ion sources, and an interface temperature of $240{ }^{\circ} \mathrm{C}$ was set for the mass spectrometer. For the ionization energy quantity, $70 \mathrm{eV}$ was used, while the electron impact (EI) mode was chosen to produce stable and reproducible mass spectra and a value range of $50-650 \mathrm{~m} / \mathrm{z}$ was used for the running of samples. The MS delay time before scanning was $5 \mathrm{~min}$. The compounds obtained was displayed in Table 2.

\section{Determination of total phenolic content}

The total phenolic content (TPC) of the extracts was evaluated using the Folin-Ciocâlteu technique as described by Gulcin et al. [35], with a few modifications. Briefly, $100 \mu \mathrm{L}(0.5 \mathrm{mg} / \mathrm{mL})$ of the polyphenol rich extracts of Ocimum G. was placed into separate plain tubes. About $500 \mu \mathrm{L}(1 \% \mathrm{v} / \mathrm{v})$ of Folin-Ciocâlteu phenol reagent was added to each tube containing the Ocimum
G. extract and the tubes were allowed to stand for $5 \mathrm{~min}$. and then vortexed. After allowing stand for $5 \mathrm{~min}$., about $400 \mu \mathrm{L}(20 \% \mathrm{w} / \mathrm{w})$ of sodium carbonate was added to the aliquots, which were then incubated in the dark at room temperature for $90 \mathrm{~min}$. For the color development. The absorbance of each mixture was evaluated with an ultraviolet-visible spectrophotometer (Beckman, DU 7400, USA) at $765 \mathrm{~nm}$. Sodium carbonate solution without any addition of Folin-Ciocâlteu phenol reagent was used as a blank. For the calibration curve, gallic acid standards were used. TPCs of the samples were determined from the linear regression of the gallic acid standards. The results were represented as the gallic acid equivalent (GAE) per gram of dry weight of Ocimum gratissimum extract (mg GAE/g). The procedure was conducted in triplicate $(n=3)$.

\section{DPPH free radical scavenging assay}

The free radical scavenging activity of the extract was determined according to the method described by Rakmai et al. [36], with slight modifications. About $2 \mathrm{~mL}$ of DPPH - methanol solution $(180 \mu \mathrm{mol} / \mathrm{L})$ was added and mixed with the extract at $0.1 \mathrm{mg} / \mathrm{mL}$. The aliquots were incubated in the dark at $25^{\circ} \mathrm{C}$. The absorbance of the sample was determined using a spectrophotometer at $517 \mathrm{~nm}$ at different time intervals between 0 and $60 \mathrm{~min}$. Aliquots of the extracts without addition of DPPHmethanol solution were used as blanks. Trolox, a synthetic analog of vitamin E, was used as a positive control. Equation below was used to evaluate the scavenging properties of the extracts. The procedure was carried out in triplicate $(n=3)$.

$$
\% \mathrm{DPPH}_{\text {scavenging }}=\frac{\left[\left(\mathrm{A}_{\text {extract }}-\mathrm{A}_{\text {blank }}\right) \times 100\right]}{\mathrm{A}_{\text {control }}}
$$

Where $A_{\text {sample }}$ is the extract + DPPH, $A_{\text {blank }}$ is the extract only, $A_{\text {control }}$ is the absorbance of the control solution (containing only DPPH).

\section{Animals care}

Twenty eight (28) male Wistar rats weighing 120-180g were used for the study. They were procured from the Animal Holding of the College of Health Sciences, Obafemi Awolowo University, Ile-Ife. All the rats were kept in convectional cages for 1 week to acclimatize to the environmental condition at $28-32^{\circ} \mathrm{C}$ and they were allowed have free access to diet and clean drinking water. The experiment was approved by the Health Research Ethics Committee (HREC) of Obafemi Awolowo University and the study has been described in accordance with the ARRIVE guidelines (animals in research: reporting in vivo experiment) [37]. 


\section{Experimental design}

The animals were divided into 4 groups of 7 rats each.

Group I: the control rats were orally treated with $2 \mathrm{~mL} / \mathrm{kg}$ of water once daily for 7 consecutive days.

Group II: rats were given $400 \mathrm{mg} / \mathrm{kg}$ body weight oral dose of PREOG for 7 consecutive days [14].

Group III (CP): rats were maintained on a rat chow for the first 4 days before injected with $\mathrm{CP}(50 \mathrm{mg} / \mathrm{kg}$ body weight, intraperitoneally [i.p.]) for the remaining 3 days of the study [11].

Group IV: rats were first pretreated with oral dose of PREOG at $400 \mathrm{mg} / \mathrm{kg}$ body weight for 4 consecutive days following intraperitoneal injection of $\mathrm{CP}$ at $50 \mathrm{mg} / \mathrm{kg}$ along with PREOG for the remaining 3 days of the study.

Measurement of urine, food consumption and body weight The urine of each rat in the groups was collected before and $24 \mathrm{~h}$ after last day of the drugs and extract of $\mathrm{Oci}$ mum G. administration for biochemical assay using metabolic cages while the food consumption and body weight of each experimental rat was measured at the beginning and the end of the experiment by digital weighing balance (Hanson, China).

\section{Biochemical analyses}

Twenty-four hours after the last treatment, the animals were sacrificed under ketamine hydrochloride anesthesia $(25 \mathrm{mg} / \mathrm{kg} / \mathrm{b} . \mathrm{w}$ via intramuscular route). Blood was collected from each animals by cardiac puncture and placed into separate lithium heparinized tubes. Blood obtained was centrifuged at $4000 \times \mathrm{g}$ for $15 \mathrm{~min}$ at $4{ }^{\circ} \mathrm{C}$ to separate the plasma. The plasma was collected into separate plain tubes for the assessment of renal functions. The left kidney of each rat was excised and homogenized in $50 \mathrm{mM}$ Tris- $\mathrm{HCl}$ buffer (pH7.4) containing $1.15 \%$ potassium chloride, and the homogenate was centrifuged at $3000 \times g$ for $15 \mathrm{~min}$. at $4{ }^{\circ} \mathrm{C}$. The supernatant was collected for the assessment of superoxide dismutase (SOD), which was assayed by the method described by Misra and Fridovich [38]. Catalase (CAT) activity that was estimated using hydrogen peroxide as substrate according to the method of Aebi [39]. Reduced glutathione (GSH), which was determined using the method described by Beutler [40]. In addition, the hydrogen peroxide was determined from the homogenate by the method of Wolff [41] while lipid peroxidation was measured as malondialdehyde (MDA) according to the method described by Ohkawa et al. [42] and expressed as micromoles of MDA per gram tissue. Myeloperoxidase (MPO) as marker of inflammation and oxidative stress was measured according to the method of $\mathrm{Xia}$ and Zweier [43]. The absorbance was read at $350 \mathrm{~nm}$. The right kidney of each rat was carefully excised, weighed and fixed in 10\% buffer formalin for histopathological studies using periodic acid-Schiff (PAS) stain.

\section{Assays of urea, creatinine, cystatin $\mathrm{C}$ and albumin}

Plasma creatinine, urea, and albumin levels were determined by biochemical kits purchased from Randox Laboratories (Crumlin, Co. Antrim, UK). The urine concentrations of the aforementioned parameters were estimated using procedures from Randox kit.

Creatinine clearance $(\mathrm{CCr})$ was subsequently calculated using the standard conventional formula as a measure of glomerular filtration rate (GFR).

$$
\mathrm{CCr}=\frac{\mathrm{U}_{\mathrm{Cr}} \times \mathrm{V}_{\mathrm{U}}}{\mathrm{P}_{\mathrm{Cr}}}
$$

where $\mathrm{U}_{\mathrm{Cr}}$ is urine creatinine concentration in $\mu \mathrm{mol} / \mathrm{L}$, $\mathrm{V}_{\mathrm{U}}$ is urine flow rate (volume of urine/time, in $\mathrm{mL}$ and $24 \mathrm{~h}$ (1440 min), respectively), and $\mathrm{P}_{\mathrm{Cr}}$ is plasma creatinine concentration in $\mu \mathrm{mol} / \mathrm{L}$. Plasma and urine cystatin $\mathrm{C}$ were determined using specific rat ELISA kits purchased from Abcam (USA).

\section{Plasma and urine concentration of electrolytes}

The plasma and urine concentrations of sodium $\left(\mathrm{Na}^{+}\right)$, chloride $\left(\mathrm{Cl}^{-}\right)$and potassium $\left(\mathrm{K}^{+}\right)$ions were measured. $\mathrm{Na}^{+}$and $\mathrm{K}^{+}$were measured by flame photometry using PFP7 (Jenway) flame photometer. $\mathrm{Cl}^{-}$was assessed by using Teco laboratory kit.

\section{Estimations of plasma C-reactive protein (CRP), interleukin- 6 and aldosterone}

Plasma CRP and aldosterone were determined using specific rat ELISA kits purchased from Abcam (USA). Plasma (IL) -6 assay was estimated according to the manufacturer's instructions using the ELISA kits obtained from Elabscience (Texas, USA).

\section{Histopathological studies}

Each rat right kidney was fixed in $10 \%$ formo-saline. The tissues were cut into $3-4 \mu \mathrm{m}$ thick sections by a microtome, fixed on the slides and stained with PAS. The slides were observed under a light microscope (Olympus $\mathrm{CH}$; Olympus, Tokyo, Japan) and photomicrographs were taken with a Leica DM 750 camera at $\times 400$ magnifications. The renal tissues section were assessed by a certified pathologist who was blinded to the experimental protocol. Glomerular damage was scored between grade 0 and 4 by the evaluation of mesangial proliferation, basal membrane thickness, and fibrinoid changes. Tubular damage was scored between grade 0 and 4 by 
the evaluation of vacuolar degeneration, desquamation, tubular degeneration, proximal tubular necrosis, and cast formation. Tubulointerstitial inflammatory infiltrates were scored between grade 0 and 2 by the evaluation of diversity of inflammatory cells in the medium and the presence of infiltrates within tubules epithelium (Table 1) [44]. Total renal damage score of $0-2$ represented none/ mild nephrotoxicity, 3-6 moderate nephrotoxicity, and 7-10 severe nephrotoxicity [44].

\section{Statistical analysis}

All data were expressed as means \pm standard errors of means (S.E.M). The statistical analysis was performed using one-way analysis of variance (ANOVA) followed by Neumann Keul's post hoc test for comparison between groups. Differences were considered significant when $p<0.05$ (Graph Pad Software Inc., San Diego, CA, USA).

\section{Results}

Gas chromatography-mass spectrometry analysis, phenolic contents and DPPH scavenging capacity of the Ocimum gratissimum leaves extract

GC-MS analysis revealed some bioactive compounds of Ocimum gratissimum leaves extract (Table 2). The polyphenolic contents of the extract was recognized by using the Folin-Ciocâlteu method (Table 2). The Total phenolic

Table 1 Nephrotoxicity scoring system in histopathology

\begin{tabular}{|c|c|c|c|}
\hline Grade & Glomerular Damage & Tubular damage & $\begin{array}{l}\text { Tubulointerstitial } \\
\text { inflammatory infiltrates }\end{array}$ \\
\hline 0 & None (Normal) & None (Normal) & None (Normal) \\
\hline 1 & $<25 \%$ of Glomeruli & $<25 \%$ of parenchymal tubules & Leucocytes only in interstitium \\
\hline 2 & $25-50 \%$ of Glomeruli & $25-50 \%$ of parenchymal tubules & $\begin{array}{l}\text { Leucocytes in both interstit- } \\
\text { ium and tubular epithelial cells }\end{array}$ \\
\hline 3 & $50-75 \%$ of Glomeruli & $50-75 \%$ of parenchymal tubules & - \\
\hline 4 & $>75 \%$ of Glomeruli & $>75 \%$ of parenchymal tubules & - \\
\hline
\end{tabular}

Total score of 0-2 represents none/mild nephrotoxicity, 3-6 moderate nephrotoxicity, 7-10 severe nephrotoxicity

Table 2 Chemical structure, phenolic contents and DPPH scavenging capacity of the Ocimum gratissimum leaves extract

\begin{tabular}{|c|c|c|c|}
\hline Retention time (min) & Chemical name & Chemical Structure & $\begin{array}{l}\text { Content } \\
\text { (\%, wt } / w t) \\
\text { OG }\end{array}$ \\
\hline 6.0010 & Methyl ester & $\mathrm{CH}_{3}-\mathrm{RCOOR}$ & 0.039 \\
\hline 6.0710 & Glycerin & $\mathrm{C}_{3} \mathrm{H}_{8} \mathrm{O}_{3}$ & 0.56 \\
\hline 17.062 & p-Cymene & $\mathrm{C}_{10} \mathrm{H}_{14}$ & 5.52 \\
\hline 20.402 & Sabinene & $\mathrm{C}_{10} \mathrm{H}_{16}$ & 4.61 \\
\hline 42.395 & 2-isopropyl-5-methylphenol (Thymol) & $\mathrm{C}_{10} \mathrm{H}_{14} \mathrm{O}$ & 0.20 \\
\hline 45.311 & a-copaene & $\mathrm{C}_{15} \mathrm{H}_{24}$ & 0.96 \\
\hline 47.012 & Trans-caryophyllene & $\mathrm{C}_{15} \mathrm{H}_{24}$ & 0.40 \\
\hline 50.005 & $\beta$-Selinene & $\mathrm{C}_{15} \mathrm{H}_{24}$ & 0.31 \\
\hline 52.102 & Phenol, 3-(1,1-dimethylethyl)-4-methoxy- & $\mathrm{C}_{12} \mathrm{H}_{18} \mathrm{O}_{2}$ & 0.90 \\
\hline 54.633 & Caryophyllene oxide & $\mathrm{C}_{15} \mathrm{H}_{24} \mathrm{O}$ & 2.07 \\
\hline 64.065 & Neophytadiene & $\mathrm{C}_{20} \mathrm{H}_{38}$ & 2.99 \\
\hline 65.100 & Phytol & $\mathrm{C}_{20} \mathrm{H}_{40} \mathrm{O}$ & 0.63 \\
\hline 70.355 & Carvacrol (2-methyl-5-(propan-2-yl)phenol & $\mathrm{C}_{10} \mathrm{H}_{14} \mathrm{O}$ & 0.92 \\
\hline \multicolumn{4}{|c|}{ Total Phenolic Content of the Extract } \\
\hline \multicolumn{2}{|l|}{ EXTRACT } & \multicolumn{2}{|l|}{ TPC (mg GAE/100 g) } \\
\hline \multicolumn{2}{|c|}{ Ocimum gratissimum leaves } & \multicolumn{2}{|l|}{$80.36 \pm 0.50$} \\
\hline \multicolumn{4}{|c|}{ DPPH Scavenging Capacity of the Extract } \\
\hline \multicolumn{2}{|c|}{ EXTRACT } & \multicolumn{2}{|c|}{ Scavenging activity $\left(\mathrm{IC}_{50} ; \mathrm{mg} / \mathrm{mL}\right)$} \\
\hline \multicolumn{2}{|l|}{ Ocimum gratissimum leaves } & \multicolumn{2}{|c|}{$22.12 \pm 0.43$} \\
\hline
\end{tabular}

Half-maximal concentration $\left(\mathrm{IC}_{50}\right)$ values for the DPPH free radical-scavenging activity assay and content of phenolic of Ocimum gratissimum extract. Values shown are means of three replicates $(n=3) \pm$ SEM 
contents (TPC) $(80.36 \pm 0.50 \mathrm{mg}$ GAE $/ 100 \mathrm{~g})$ obtained in Ocimum G. extract revealed that Ocimum gratissimum extract are rich in phenolic contents.

The DPPH scavenging capacity of the extract was also evaluated by calculating the $\mathrm{IC}_{50}$ value, which relates to the amount of extract that is capable of scavenging 50\% of the free radicals contained in the reaction mixture. The IC $_{50}(22.12 \pm 0.43 \mathrm{mg} / \mathrm{ml})$ value of the extract was high and this denoted high antioxidant activity of Ocimum gratissimum leaves. Thus the function of the plant high phenolic content was shown in its ability to scavenge free radical activity (Table 2 ).

\section{Effect of PREOG and cyclophosphamide on water consumption $(\mathrm{ml})$, urine output $(\mathrm{ml})$, food consumption and body weight $(\mathrm{g})$ of the rats}

The water consumption and urine output of rats treated with $\mathrm{CP}$ only were significantly higher $(p<0.05)$ when compared with the control and PREOG + CP groups. However, the rats in PREOG $+\mathrm{CP}$ group had no significant difference $(p>0.05)$ in water consumption and urine output when compared with the control (Table 3).

Table 3 Effects of polyphenol rich extract of Ocimum gratissimum leaves on water intake, urine output, food consumption (g) and body weight ( $\mathrm{g}$ ) in cyclophosphamidetreated rats

\begin{tabular}{|c|c|c|}
\hline & Baseline & $\begin{array}{l}24 \mathrm{~h} \text {. after } 7 \text { days of } \\
\text { administration of } \\
\text { drugs }\end{array}$ \\
\hline \multicolumn{3}{|l|}{ Water Intake (ml/24 h) } \\
\hline [1] Control & $17.70 \pm 0.40$ & $18.70 \pm 0.59$ \\
\hline [2] PREOG $400 \mathrm{mg} / \mathrm{kg}$ & $15.70 \pm 0.73$ & $19.60 \pm 0.43$ \\
\hline [3] CP (50 mg/kg) & $18.30 \pm 1.69$ & $30.80 \pm 1.33^{*}$ \\
\hline [4] PREOG $400 \mathrm{mg} / \mathrm{kg}+\mathrm{CP}$ & $15.90 \pm 1.76$ & $20.10 \pm 1.66^{\#}$ \\
\hline \multicolumn{3}{|l|}{ Urine Output (ml/24h.) } \\
\hline [1] Control & $12.60 \pm 0.21$ & $13.10 \pm 0.19$ \\
\hline [2] PREOG (400 mg/kg) & $13.10 \pm 0.35$ & $14.60 \pm 0.33$ \\
\hline [3] CP (50 mg/kg) & $14.00 \pm 1.39$ & $20.85 \pm 1.03^{*}$ \\
\hline [4] PREOG $(400 \mathrm{mg} / \mathrm{kg})+\mathrm{CP}$ & $14.11 \pm 1.44$ & $16.00 \pm 1.46^{\#}$ \\
\hline \multicolumn{3}{|l|}{ Food consumption (g) } \\
\hline [1] Control & $11.60 \pm 0.80$ & $15.80 \pm 0.13$ \\
\hline [2] PREOG (400 mg/kg) & $14.80 \pm 0.43$ & $20.60 \pm 0.33$ \\
\hline [3] CP (50 mg/kg) & $12.80 \pm 1.29$ & $10.06 \pm 1.03^{*}$ \\
\hline [4] PREOG $(400 \mathrm{mg} / \mathrm{kg})+\mathrm{CP}$ & $12.20 \pm 1.42$ & $14.50 \pm 1.06^{\#}$ \\
\hline \multicolumn{3}{|l|}{ Body weight (g) } \\
\hline [1] Control & $135.40 \pm 3.37$ & $150.00 \pm 2.44$ \\
\hline [2] PREOG (400 mg/kg) & $150.00 \pm 1.75$ & $170.20 \pm 4.00$ \\
\hline [3] CP (50 mg/kg) & $145.20 \pm 4.89$ & $129.10 \pm 2.01^{*}$ \\
\hline [4] PREOG $(400 \mathrm{mg} / \mathrm{kg})+\mathrm{CP}$ & $150.60 \pm 6.47$ & $146.40 \pm 3.16^{\#}$ \\
\hline
\end{tabular}

Each value represents mean $\pm \operatorname{SEM}(n=7) .{ }^{*}(p<0.05)=$ significantly different from control in the same column. ${ }^{\#}(p<0.05)=$ significantly different from CP $(50 \mathrm{mg} / \mathrm{kg})$ in the same column
The group treated with $\mathrm{CP}$ only had lowered food intake and body weight when compared with the control and PREOG + CP groups. However, the rats in PREOG $+\mathrm{CP}$ group exhibited no significant difference $(p>0.05)$ in food intake and body weight when compared with the control (Table 3).

\section{Effect of PREOG and cyclophosphamide on some parameter of renal of functions}

The plasma creatinine, urea, cystatin $C$ and albumin of $\mathrm{CP}$ treated group were significantly elevated in comparison to the control $(p<0.05)$ (Table 4). However, the urinary output of these parameters (creatinine, urea, cystatin $C$ and albumin) remained significantly reduced

Table 4 Effects of polyphenol rich extract of Ocimum gratissimum leaves on some parameter of renal function in cyclophosphamide-treated rats

\begin{tabular}{|c|c|c|}
\hline $\begin{array}{l}\text { Creatinine Concentration } \\
\text { Groups }\end{array}$ & $\begin{array}{l}\text { Plasma Level } \\
(\mu \mathrm{mol} / \mathrm{L})\end{array}$ & $\begin{array}{l}\text { Urine Level } \\
(\mu \mathrm{mol} / \mathrm{L})\end{array}$ \\
\hline [1] Control & $34.48 \pm 4.33$ & $1768.4 \pm 5.56$ \\
\hline [2] PREOG (400 mg/kg) & $39.79 \pm 2.38$ & $1945.24 \pm 8.65$ \\
\hline [3] CP (50 mg/kg) & $168.00 \pm 3.23^{*}$ & $970.85 \pm 4.33^{*}$ \\
\hline [4] PREOG $(400 \mathrm{mg} / \mathrm{kg})+\mathrm{CP}$ & $44.21 \pm 4.57^{\#}$ & $1670.25 \pm 6.45^{\#}$ \\
\hline Urea Concentration & Plasma Level & Urine Level \\
\hline Groups & $(\mathrm{mmol} / \mathrm{L})$ & $(\mathrm{mmol} / \mathrm{L})$ \\
\hline [1] Control & $5.90 \pm 0.27$ & $200.02 \pm 21.39$ \\
\hline [2] PREOG (400 mg/kg) & $7.00 \pm 0.92$ & $200.90 \pm 15.88$ \\
\hline [3] CP (50 mg/kg) & $16.70 \pm 5.26^{*}$ & $130.03 \pm 20.19^{*}$ \\
\hline [4] PREOG $(400 \mathrm{mg} / \mathrm{kg})+\mathrm{CP}$ & $11.95 \pm 0.42^{* \#}$ & $179.67 \pm 30.38^{\#}$ \\
\hline Cystatin C Concentration & Plasma Level & Urine Level \\
\hline Groups & $(\mathrm{ng} / \mathrm{ml})$ & $(\mathrm{ng} / \mathrm{ml})$ \\
\hline [1] Control & $0.23 \pm 0.31$ & $12.34 \pm 3.01$ \\
\hline [2] PREOG (400 mg/kg) & $0.25 \pm 0.44$ & $13.30 \pm 2.08$ \\
\hline [3] CP (50 mg/kg) & $0.59 \pm 0.66^{*}$ & $25.34 \pm 1.19^{*}$ \\
\hline [4] PREOG $(400 \mathrm{mg} / \mathrm{kg})+\mathrm{CP}$ & $0.43 \pm 0.23^{\#}$ & $15.08 \pm 1.38^{\#}$ \\
\hline Albumin & Plasma Level & Urine Level \\
\hline Groups & $(g / d l)$ & $(\mathrm{mg} / \mathrm{dl})$ \\
\hline [1] Control & $6.44 \pm 0.55$ & $0.19 \pm 0.71$ \\
\hline [2] PREOG (400 mg/kg) & $7.09 \pm 0.21$ & $0.22 \pm 1.01$ \\
\hline [3] CP (50 mg/kg) & $3.22 \pm 0.25^{*}$ & $1.25 \pm 0.91^{*}$ \\
\hline [4] PREOG $(400 \mathrm{mg} / \mathrm{kg})+\mathrm{CP}$ & $5.78 \pm 1.01^{\#}$ & $0.28 \pm 0.08^{\#}$ \\
\hline Albumin/Creatinine Ratio & $(\mathrm{mg} / \mathrm{g})$ & \\
\hline \multicolumn{3}{|l|}{ Groups } \\
\hline [1] Control & $9.91 \pm 0.51$ & \\
\hline [2] PREOG (400 mg/kg) & $10.70 \pm 1.32$ & \\
\hline [3] CP $(50 \mathrm{mg} / \mathrm{kg})$ & $113.8 \pm 4.66^{*}$ & \\
\hline [4] PREOG $(400 \mathrm{mg} / \mathrm{kg})+\mathrm{CP}$ & $14.80 \pm 0.52^{\#}$ & \\
\hline
\end{tabular}

Each value represents mean $\pm \operatorname{SEM}(n=7) .{ }^{*}(p<0.05)=$ significantly different from control in the same column. ${ }^{*}(p<0.05)=$ significantly different from CP $(50 \mathrm{mg} / \mathrm{kg})$ in the same column 
when compared with the control. The PREOG group had no significant difference $(p>0.05)$ in the plasma and urine levels of creatinine, urea, cystatin $C$ and albumin, except the plasma urea that showed elevated level when compared with control (Table 4). Thus, the polyphenol rich extract of Ocimum gratissimum leaves prevented the adverse effect of $\mathrm{CP}$ on the aforementioned parameters (Table 4).

Albumin - to - creatinine ratio of CP group was significantly higher $(p<0.05)$ when compared with control and PREOG groups. The PREOG group exhibited no significant difference $(p>0.05)$ in Albumin - to - creatinine ratio when compared with the control (Table 4 ).

\section{Effect of PREOG and cyclophosphamide on creatinine clearance}

A significant decrease in the renal creatinine clearance was observed in the CP alone group when compared with the control $(p<0.05)$. However, the PREOG-treated groups revealed a significant increase in the creatinine clearance when compared with $\mathrm{CP}$ alone treated group $(p<0.05)$ (Fig. 1).

\section{Effect of PREOG and cyclophosphamide on plasma and urine electrolytes}

Treatment of rats with $\mathrm{CP}$ alone showed a significantly lower in plasma $\mathrm{Na}^{+}$and $\mathrm{Cl}^{-}$concentrations, but a significantly higher in plasma $\mathrm{K}^{+}$concentration compared with the control group. The urine concentrations of $\mathrm{Na}^{+}$and $\mathrm{Cl}^{-}$were significantly higher in the $\mathrm{CP}$ alone group when compared with control and PREOG $+\mathrm{CP}$ groups. However, the urine excretion of $\mathrm{K}^{+}$was significantly lower when compared with the control and PREOG + CP. On the other hand, treatment with PROEOG significantly alleviated the aforementioned parameters (Table 5).

\section{Effect of PREOG and cyclophosphamide on aldosterone} CP treated group exhibited lower aldosterone level when compared with the control $(p<0.05)$. However, the PREOG-treated groups had significantly higher

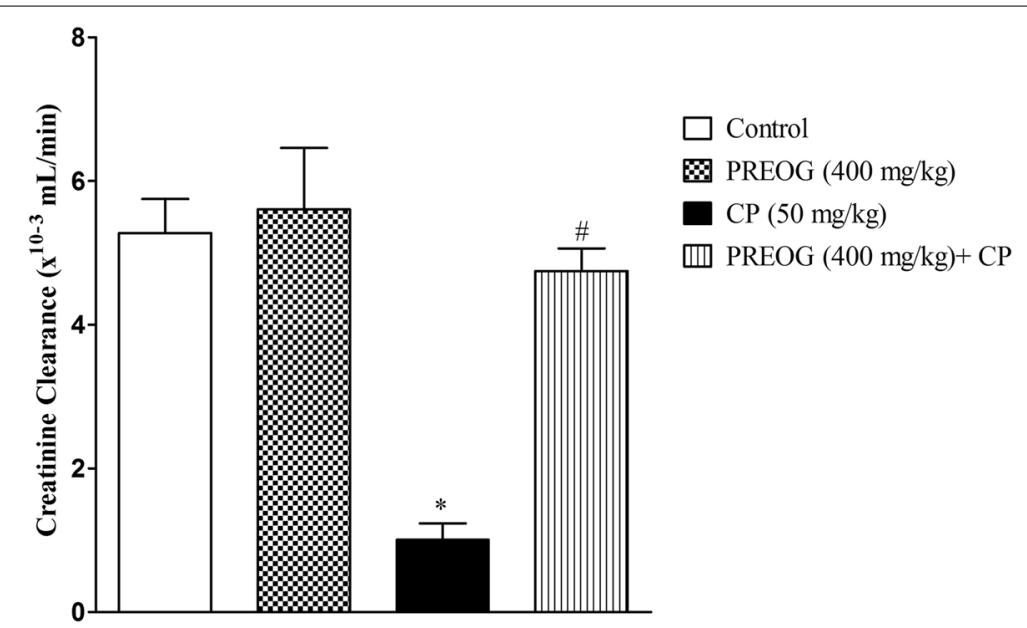

Fig. 1 Effects of Polyphenol Rich Extract of Ocimum gratissimum Leaves on Creatinine Clearance in Cyclophosphamide-Treated Rats. Each value represents mean $\pm \operatorname{SEM}(n=7) .{ }^{*}(p<0.05)=$ significantly different from control. ${ }^{*}(p<0.05)=$ significantly different from CP $(50 \mathrm{mg} / \mathrm{kg})$

Table 5 Effects of polyphenol rich extract of Ocimum gratissimum leaves on plasma and urine electrolytes in cyclophosphamidetreated rats

\begin{tabular}{|c|c|c|c|c|c|c|}
\hline \multirow[t]{3}{*}{ Groups } & \multicolumn{3}{|c|}{ Plasma Electrolytes } & \multicolumn{3}{|c|}{ Urine Electrolytes } \\
\hline & $\mathrm{Na}^{+}$ & $\mathrm{K}^{+}$ & $\mathrm{Cl}^{-}$ & $\mathrm{Na}^{+}$ & $\mathrm{K}^{+}$ & $\mathrm{Cl}^{-}$ \\
\hline & $(\mathrm{mmol} / \mathrm{L})$ & $(\mathrm{mmol} / \mathrm{L})$ & $(\mathrm{mmol} / \mathrm{L})$ & $(\mathrm{mmol} / \mathrm{L})$ & $(\mathrm{mmol} / \mathrm{L})$ & $(\mathrm{mmol} / \mathrm{L})$ \\
\hline [1] Control & $149.80 \pm 2.58$ & $5.08 \pm 0.12$ & $112.20 \pm 3.49$ & $155.0 \pm 5.53$ & $134.87 \pm 6.38$ & $130.00 \pm 2.45$ \\
\hline [2] PREOG & $152.70 \pm 2.80$ & $5.12 \pm 0.10$ & $118.80 \pm 4.01$ & $158.00 \pm 5.00$ & $140.03 \pm 3.91$ & $138.67 \pm 1.38$ \\
\hline [3] CP & $131.00 \pm 5.10^{*}$ & $6.96 \pm 0.13^{*}$ & $96.20 \pm 6.76^{*}$ & $202.00 \pm 9.13^{*}$ & $98.00 \pm 2.05^{*}$ & $192.00 \pm 5.67^{*}$ \\
\hline [4] PREOG + CP & $142.90 \pm 2.06^{\#}$ & $5.45 \pm 0.09^{\#}$ & $108.20 \pm 2.99^{\#}$ & $166.00 \pm 5.07^{\#}$ & $129.89 \pm 1.24^{\#}$ & $140.10 \pm 6.09^{\#}$ \\
\hline
\end{tabular}

Each value represents mean $\pm \operatorname{SEM}(n=7) .{ }^{*}(p<0.05)=$ significantly different from control in the same column. ${ }^{*}(p<0.05)=$ significantly different from CP $(50 \mathrm{mg} / \mathrm{kg})$ in the same column 
aldosterone level in comparison to $\mathrm{CP}$ alone treated group $(p<0.05)$ (Fig. 2).

\section{Effect of PREOG and cyclophosphamide on interleukin- 6 and $\mathrm{C}$ - reactive protein}

Figures 3 and 4 show the effect of PREOG and CP on markers of inflammation (IL-6 and C - reactive protein) in the plasma. There was a significantly increased levels of interleukin- 6 and C-reactive protein in the plasma of rats treated with $\mathrm{CP}$ alone when compared with control $(p<0.05)$. Polyphenol extract of Ocimum gratissimum leaves significantly decreased the elevated plasma IL-6 and C-reactive protein levels compared to CP-treated group $(p<0.05)$.
PREOG repressed oxidative stress and improved antioxidant enzyme activities

Table 6 shows the effect of PREOG on the kidney antioxidant enzymes (SOD and CAT) activities, GSH, MDA and $\mathrm{H}_{2} \mathrm{O}_{2}$ levels. The present findings show that $\mathrm{CP}$ significantly decreased $(p<0.05)$ renal activities of SOD, and CAT, along with GSH level, whereas MDA and $\mathrm{H}_{2} \mathrm{O}_{2}$ levels were significantly increased $(p<0.05)$ compared to the control. In contrast, PREOG significantly restored the renal SOD, and CAT activities, as well as GSH, MDA and $\mathrm{H}_{2} \mathrm{O}_{2}$ levels to normalcy. The observed alleviation of oxidative stress in PREOG $+\mathrm{CP}$ treated group indicate free radicals scavenging ability of the plant extract against CP-induced renotoxicity.

Myeloperoxidase activity was significantly higher in $\mathrm{CP}$ alone treated group when compared with the control. However, PREOG significantly decreased the

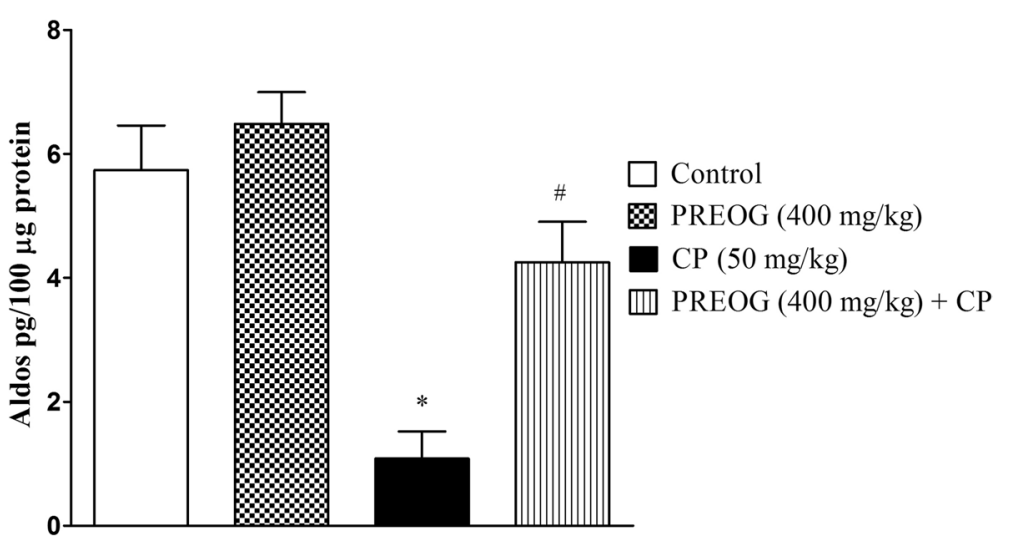

Fig. 2 Effects of Polyphenol Rich Extract of Ocimum gratissimum Leaves on Aldosterone in Cyclophosphamide-Treated Rats. Each value represents mean $\pm \operatorname{SEM}(n=7) .{ }^{*}(p<0.05)=$ significantly different from control. ${ }^{*}(p<0.05)=$ significantly different from CP $(50 \mathrm{mg} / \mathrm{kg})$

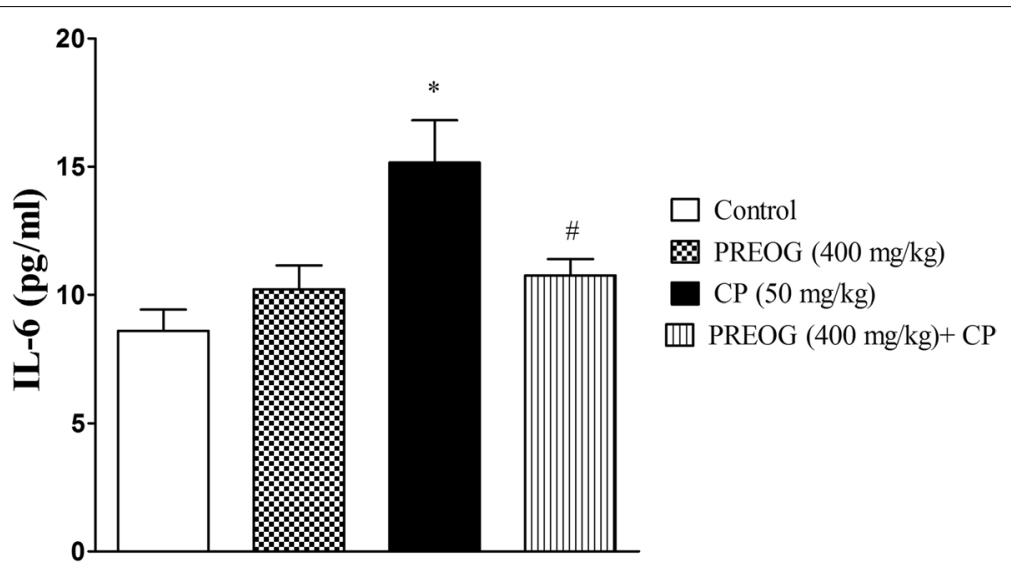

Fig. 3 Effects of Polyphenol Rich Extract of Ocimum gratissimum Leaves on Interleukin-6 in Cyclophosphamide-Treated Rats. Each value represents mean $\pm \operatorname{SEM}(n=7) .{ }^{*}(p<0.05)=$ significantly different from control. ${ }^{*}(p<0.05)=$ significantly different from CP $(50 \mathrm{mg} / \mathrm{kg})$ 


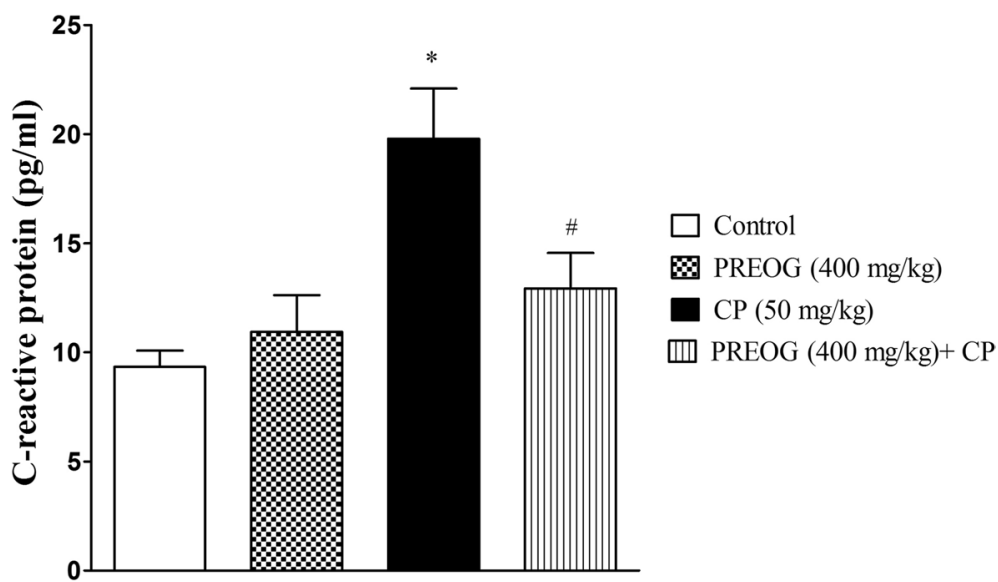

Fig. 4 Effects of Polyphenol Rich Extract of Ocimum gratissimum Leaves on C-reactive protein in Cyclophosphamide-Treated Rats. Each value represents mean $\pm \operatorname{SEM}(n=7) .{ }^{*}(p<0.05)=$ significantly different from control. ${ }^{*}(p<0.05)=$ significantly different from CP $(50 \mathrm{mg} / \mathrm{kg})$

Table 6 Effects of polyphenol rich extract of Ocimum gratissimum leaves on oxidative stress and cellular infiltration indices in cyclophosphamide-treated rats

\begin{tabular}{|c|c|c|c|c|c|c|}
\hline Groups & $\begin{array}{l}\text { Kidney SOD ( } \mu \text { / } \\
\text { mg protein) }\end{array}$ & $\begin{array}{l}\text { Kidney CAT }(\mu \mathrm{M} / \\
\text { mg protein) }\end{array}$ & $\begin{array}{l}\text { Kidney GSH ( } \mu \mathrm{g} / \\
\text { mg protein) }\end{array}$ & $\begin{array}{l}\text { Kidney MDA (nM/ } \\
\text { mg protein) }\end{array}$ & $\begin{array}{l}\text { Kidney } \mathrm{H}_{2} \mathrm{O}_{2} \\
\text { (nM/g protein) }\end{array}$ & $\begin{array}{l}\text { Kidney } \\
\text { MPO (U/mg } \\
\text { protein) }\end{array}$ \\
\hline [1] Control & $2.35 \pm 0.27$ & $5.01 \pm 0.35$ & $10.04 . \pm 0.21$ & $14.54 \pm 0.46$ & $24.00 \pm 1.31$ & $6.94 \pm 4.05$ \\
\hline [2] PREOG (400 mg/kg) & $2.40 \pm 0.03$ & $6.08 \pm 1.10$ & $11.43 \pm 0.30$ & $16.02 \pm 2.37$ & $24.89 \pm 2.30$ & $7.09 \pm 4.21$ \\
\hline [3] CP $(50 \mathrm{mg} / \mathrm{kg})$ & $1.12 \pm 1.14^{*}$ & $2.01 \pm 0.30^{*}$ & $5.40 \pm 1.45^{*}$ & $30.90 \pm 1.62^{*}$ & $40.84 \pm 3.13^{*}$ & $35.02 \pm 6.06^{*}$ \\
\hline [4] PREOG $(400 \mathrm{mg} / \mathrm{kg})+\mathrm{CP}$ & $2.00 \pm 0.20^{\#}$ & $4.01 \pm 0.15^{\#}$ & $9.43 \pm 1.56^{\#}$ & $18.31 \pm 1.64^{\#}$ & $29.09 \pm 4.06^{\#}$ & $16.08 \pm 3.31^{* \#}$ \\
\hline
\end{tabular}

Each value represents mean $\pm \operatorname{SEM}(n=7) .{ }^{*}(p<0.05)=$ significantly different from control in the same column. ${ }^{*}(p<0.05)=$ significantly different from CP $(50 \mathrm{mg} / \mathrm{kg})$ in the same column

elevated MPO activity compared to the CP treated group (Table 6).

\section{PREOG improves histopathological alterations in the kidney tissue}

The histoarchitecture of the control, and PREOG groups showed normal glomeruli and tubules as well intact blood vessels (Fig. 5). Histoarchitecture of $\mathrm{CP}$ showed marked alteration of glomeruli and proximal and distal convoluted tubules damage. Infiltration of the interstitium by chronic inflammatory cells mostly neutrophils were also seen in CP treated rats. However, PREOG $+\mathrm{CP}$ group showed mild alteration in glomeruli and mild infiltration of the interstitium with inflammatory cells. The proximal and distal convoluted tubules and loop of Henle were intact in this group than $\mathrm{CP}$ alone group (Fig. 5). The total nephrotoxicity score of $\mathrm{CP}$ alone was significantly higher than that the control and PREOG + CP groups $(p<0.05)$ (Table 7$)$.

\section{Discussion}

In the current study, there are indications of elevated levels in the parameters of oxidative stress such as lipid peroxidation, hydrogen peroxide $\left(\mathrm{H}_{2} \mathrm{O}_{2}\right)$, and nitric oxide $(\mathrm{NO})$, suggesting that the membrane lipids and protein of the kidney of the rats treated with $\mathrm{CP}$ alone were damaged. Also, the activities of antioxidant enzymes such as superoxide dismutase and catalase and level of non-enzymatic antioxidant, reduced glutathione were decreased in the group treated with $\mathrm{CP}$ alone. The decrease in antioxidants in the renal cells of the rats treated with $\mathrm{CP}$ alone was an indication of redox-homeostasis imbalance. CP has been previously shown to induce oxidative damage, inflammation, and cell necrosis or apoptosis after activation and promotion of reactive oxygen species (ROS) via its metabolite, acrolein [7, 11, 14], which subsequently trigger the deactivation and diminishing of antioxidant defense capacities of the affected organisms [10, 11, 45]. In this study, the overproduction of ROS outweighs the endogenous antioxidant capacity, triggers oxidative 

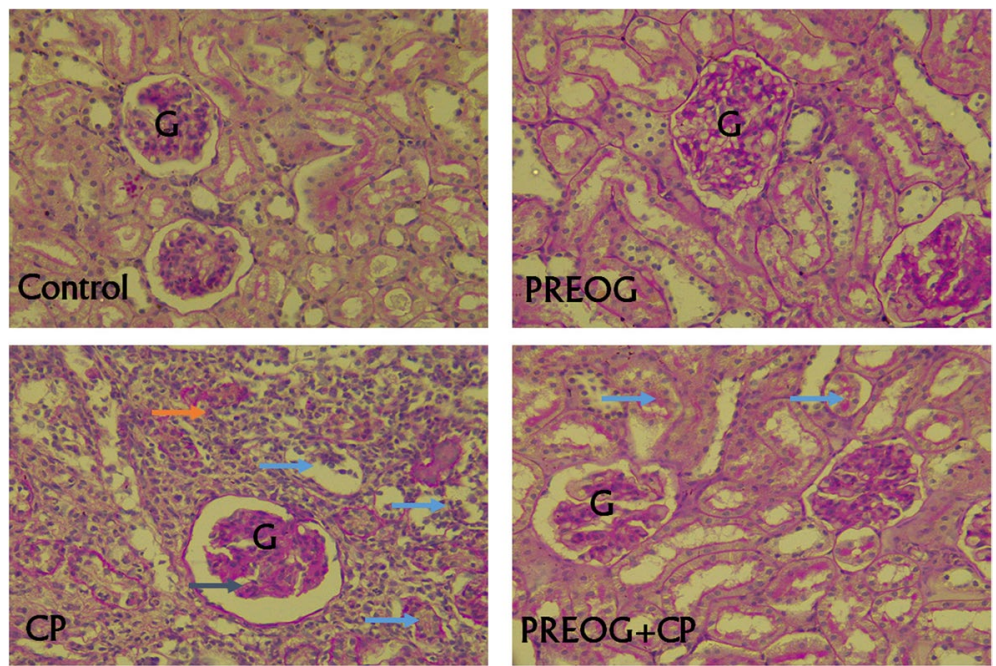

Fig. 5 The histoarchitecture of the control, and PREOG groups show normal renal parenchymal tissue with intact glomeruli, proximal and distal convoluted tubules and loop of Henle. The blood vessels are intact. Histoarchitecture of CP shows renal tissue with marked alteration of the renal parenchymal tissue owing to severe destruction/damage of the glomeruli (black arrow), proximal and distal convoluted tubules (blue arrows). Infiltration of the interstitium by chronic inflammatory cells mostly neutrophils were also seen in CP treated rats (brown arrow). However, PREOG + CP group renal architecture show mild alteration in glomeruli and mild infiltration of the interstitium with inflammatory cells. The proximal and distal convoluted tubules and loop of Henle were intact in this group than CP alone group (PAS, X400)

Table 7 Histopathological nephrotoxicity scores of the experimental groups

\begin{tabular}{|c|c|c|c|c|c|c|c|c|c|c|c|c|c|c|c|c|c|c|}
\hline \multirow[t]{2}{*}{ Group } & \multicolumn{6}{|c|}{ Glomerular damage } & \multicolumn{6}{|c|}{ Tubular damage } & \multicolumn{4}{|c|}{$\begin{array}{l}\text { Tubulointerstitial } \\
\text { inflammatory infiltrate }\end{array}$} & \multirow{2}{*}{$\begin{array}{l}\text { Total } \\
\text { nephrotoxicity } \\
\text { score }\end{array}$} & \multirow[t]{2}{*}{ Average } \\
\hline & Go & G1 & G2 & G3 & G4 & Average & G0 & G1 & G2 & G3 & G4 & Average & G0 & G1 & G2 & Average & & \\
\hline 1. Control & 7 & 0 & 0 & 0 & 0 & 0.0 & 7 & 0 & 0 & 0 & 0 & 0.0 & 7 & 0 & 0 & 0.0 & 0 & 0.0 \\
\hline 2. PREOG & 7 & 0 & 0 & 0 & 0 & 0.0 & 7 & 0 & 0 & 0 & 0 & 0.0 & 7 & 0 & 0 & 0.0 & 0 & 0.0 \\
\hline 3. CP & 4 & 0 & 1 & 1 & 1 & $0.60^{*}$ & 3 & 0 & 1 & 1 & 2 & $1.40^{*}$ & 5 & 0 & 2 & $0.48^{*}$ & 7 & $0.76^{*}$ \\
\hline 4. $P R E O G+C P$ & 6 & 1 & 0 & 0 & 0 & $0.20^{\#}$ & 6 & 1 & 0 & 0 & 0 & $0.20^{\#}$ & 6 & 1 & 0 & $0.20^{\#}$ & 2 & $0.12^{\#}$ \\
\hline
\end{tabular}

Total score of $0-2$ represents none/mild nephrotoxicity, 3-6 moderate nephrotoxicity, 7-10 severe nephrotoxicity

G Grade

Each value represents mean $\pm \operatorname{SEM}(n=7) .{ }^{*}(p<0.05)=$ significantly different from control. ${ }^{*}(p<0.05)=$ significantly different from $\mathrm{CP}(50 \mathrm{mg} / \mathrm{kg})$

stress, and subsequently damages renal cells of the CPtreated rats as was reflected by the increased levels of markers of oxidative stress and decreased levels of antioxidant parameters. Also, the histology view of these rats showed glomerular damage and tubular necrosis of the renal cells.

Furthermore, redox imbalance elicits proinflammatory cytokines overproduction $[3,14]$. The observed overproduction of ROS triggered lipid peroxidation and mobilization of proinflammatory cytokines and concurrently exerted inflammatory renal cell damage. IL-6 assessment in this study was significantly elevated in CP-treated rats, which indicates oxidative stress attack and inflammation of the renal cells. IL- 6 elevation has been found to trigger and/or stimulate the liver to initiate acute phase response that results in an increase in circulating C-reactive protein (CRP) production and other bioactive mediators [46]. CRP was significantly increased in CP-treated rats and the elevated level of this biomarker was an indication of an early defense system against infections, inflammation, and tissue damage $[47,48]$. The elevation of the CRP level in this study further confirmed undergoing inflammation in the rats treated with $\mathrm{CP}$ alone. $\mathrm{CP}$ has been observed to trigger the reduction of the kidney's endogenous antioxidants such as overutilization of GSH by the kidney due to accumulation of cyclophosphamide metabolite products in the renal tubular cells [9]. As a result of this process, the kidney of rats treated with $\mathrm{CP}$ alone could upsurge immune response against its cells, which subsequently resulted in inflammation as shown 
by the elevation of the plasma CRP. In agreement, CP has the potential of inducing inflammation and likely immunological damage in the kidney of CP-treated rats.

GC - MS analysis confirmed some vital bioactive components of Ocimum G. extract and Folin-Ciocâlteu routine revealed high phenolic contents of the extract. The observed polyphenol-rich of the plant increases its antioxidant capacity against the free radicals as was revealed by the DPPH scavenging capacity of the Ocimum G. extract. This proved the antioxidative and anti-inflammatory effect of PREOG in vitro.

Co-administration of PREOG and CP show promising therapeutic advantages over $\mathrm{CP}$ treated group alone on the kidney tissue. The increase in antioxidant expression levels (SOD, CAT, and GSH) and decrease in oxidative stress markers (lipid peroxidation, $\mathrm{H}_{2} \mathrm{O}_{2}$, and $\mathrm{NO}$ ) seen in Ocimum G. extract groups indicated that Ocimum G. extracts improved antioxidant capacities and prevented renal oxidative damage via suppressing the overproduction of ROS in rats being exposed to CP toxicity. These indications proved the antioxidant and anti-inflammatory capacity of PREOG in vivo. This study is in line with the previous studies that reported residual antioxidative, anti-inflammatory, and antibacterial activities of Ocimum $G[14,18,19]$..

The undergoing inflammation in the renal tissue of rats treated with $\mathrm{CP}$ was also confirmed by an elevated level of myeloperoxidase (MPO). MPO is a marker of leukocyte infiltration and inflammatory conditions [49]. The activity of this enzyme is higher when inflammation occurs in the blood and tissues and is usually used to assess the severity of inflammation $[49,50]$. MPO is found in azurophilic granules of neutrophils and macrophages. The elevated activity of this enzyme is an indication of infiltration of inflammatory cells in the kidney or other organs $[49,51]$. The inflammatory process was also confirmed by the histopathological study, showing neutrophil infiltration and tubular necrosis in the renal cells of CP-treated rats. Thus, induction of inflammation is the main pathological manifestation of $\mathrm{CP}$ organ toxicity [7]. However, in this study, the administration of polyphenol-rich extract of Ocimum G., reduced MPO activity, indicating inhibition of leucocytes infiltration and inflammation in the kidney.

As a result of the overproduction of ROS and oxidative damage of the renal cells induced by $\mathrm{CP}$ assault, the markers of renal function test such as plasma creatinine and urea level were significantly elevated in the group treated with $\mathrm{CP}$ alone which indicated marked renal impairment. The significant increase in plasma creatinine and urea levels and subsequently decrease in urine output is indicative of renal dysfunction [52]. CP-induced renal impairment was associated with an excessive increase in plasma and urinary output of cystatin C levels, which is reported to be a more sensitive marker for the diagnosis of acute kidney injury over creatinine and urea [53]. The significant increase of cystatin $C$ level in the urine further confirmed renal dysfunction and damage in the CP-treated group. The severity of CP-induced renal dysfunction was confirmed by histopathological examination, which revealed distortion of the glomeruli, proximal and distal renal tubules. However, administration of PREOG prevented the adverse side effect of CP on some markers of renal function such as plasma levels of creatinine, urea, and cystatin $C$ and urine levels of these markers, indicating improved kidney function. These results are consistent with those reported by Ogundipe et al. [54], where the extract of Ocimum G. significantly inhibited the actions of ROS in the kidney of gentamicintreated rats. ROS have been found to cause kidney function alteration, tissue necrosis and the inability of the kidney to filter or secrete urea and creatinine from the body of the animals. Interestingly, the protective effect of PREOG in the kidneys of rats imply that leave extract of Ocimum G. possesses some essential antioxidant compounds as reflected in GC-MS analysis, and the antioxidant activities of Ocimum G. might be the reason for the reduction in the ROS and other reactive by-products generated by $\mathrm{CP}$ toxic metabolites in the kidney tissue of rats co-treated with PREOG and CP. Indeed, the histopathological study showed evidence of improvement in the structure of the kidney of the PREOG + CP cotreated than the CP-treated group.

Albumin is one of the carrier proteins that function to maintain oncotic pressure and extracellular fluid volume. Normal kidney function prevents this protein from passing through its filtration barrier, however, damage to the kidney structure, particularly the filtration barrier of the glomeruli, allows the filtration of this protein to pass through and subsequently being detectable in the urine. The significant decrease in the plasma level and increase in the urinary output of albumin in CP-treated rats indicated kidney dysfunction, which reflects glomerular filtration barrier dysfunction/damage. Albuminto-creatinine ratio was used to assess albuminuria or microalbuminuria (glomerular filtration function). The presence of albuminuria or microalbuminuria is an indication of glomerular filtration dysfunction and microand macro-vascular dysfunctions $[55,56]$. Results of this study suggested that $\mathrm{CP}$ contributes to glomerular filtration and endothelial dysfunction. This study was in tandem with the previous observations on the effects of $C P$ on endothelium dysfunctions $[57,58]$. However, PREOG treatment showed a significant increase in the plasma and decreased urine output of albumin. Also, albuminto-creatinine ratio assessment in the PREOG-treated 
group was significantly decreased compared with CPtreated rats. These indicated that PREOG improved endothelial function and glomerular filtration membrane thereby increasing glomeruli blood perfusion.

The creatinine clearance (Ccr) assessment in this study was significantly reduced in CP-treated rats, which indicates reduced perfusion of the glomeruli. The reduction in the renal glomeruli perfusion could be due to the renal vascular constriction and/or damage to the glomerular capillary endothelium and these resulted in a reduced glomerular filtration rate. The significant decrease in creatinine clearance that was observed in the CP-treated rats is an indication of alteration of the glomerular filtration function. However, Ccr of the PREOG-treated group was significantly elevated, which indicates improved renal blood flow and glomerular filtration rate. The photomicrograph of the PREOG-treated rats further confirmed the improved renal glomeruli function.

Electrolytes are essential ions in the blood for homeostasis. However, alteration in renal function due to exposure to toxic substances could result in irregularities in the body electrolytes level [52]. The plasma sodium and chloride ions in this study were significantly lowered in $\mathrm{CP}$-treated rats, suggesting cases of hyponatremia and hypochloremia. Moreover, the assessment of the urinary output of these two ions showed significant increases, which indicates an alteration in renal handling of these ions. Cyclophosphamide has been known to induce excessive sodium loss through the urine by stimulating the production of antidiuretic hormone from the hypothalamus, which therefore influences a decrease in aldosterone secretion from the adrenal cortex $[59,60]$. A significant reduction of aldosterone was noted in CPtreated rats in this study. The decreased aldosterone production reduced sodium ion reabsorption in the distal convoluted tubules of the kidney nephron. The increased urinary output and decreased plasma level of sodium ion that was observed in this study was due to cyclophosphamide toxic metabolite effect on posterior pituitary, which increases $\mathrm{ADH}$ production to enhance water retention and indirectly halted aldosterone secretion from the adrenal cortex and thereby influences large urinary sodium excretion in the rats. However, PREOG administration normalized plasma sodium level either by activating or increasing aldosterone secretion in the adrenal cortex, thereby maintaining the amount of sodium excretion in the urine of the rats co-treated with PREOG $+\mathrm{CP}$ compared with the CP-treated rats.

The water intake and urine excretion of CP-treated rats significantly increased than those treated with PREOG. The sodium loss in this study could be the reason for the polyuria and polydipsia that were observed in the CP-treated group. PREOG administration prevented excessive sodium and water loss through urine in rats co-treated with PREOG + CP compared with the CPtreated rats.

Plasma potassium level was significantly increased and significantly lowered in the urine of CP-treated rats. Hyperkalemia is one of the markers of renal injury because it depends on the glomerular filtration and tubular secretion for excretion $[44,61]$. The excessive elevated level of plasma potassium ion that was observed is a sign of compromised renal function, particularly tubular damage, and could also be linked to cardiovascular diseases risk of $\mathrm{CP}$ effect. However, treatment with PREOG restored plasma potassium level and prevented $\mathrm{CP}$-induced hyperkalemia in treated rats. This attribute indicates that polyphenol-rich extract of Ocimum gratissimum leaves have antioxidant and membrane stabilizing properties.

Cyclophosphamide treatment in this study was associated with anorexia, a significant reduction in food intake, and mild tiredness. This explains the reduction in body weight that was observed in the animals. Healthy body weight is a product of an equilibrium between food consumption and the rate of energy expenditure [44]. Hence, the bodyweight reduction and anorexia that were observed could be due to $\mathrm{CP}$ exposure effect on gastrointestinal disturbance [62]. However, the administration of PREOG improved food consumption and prevented the reduction in body weight and enhanced fitness of the rats. This finding is in support of Ogundipe et al. [63], who reported an increase in body weight of rats treated with extract of Ocimum G. after gentamicin administration. This suggests that Ocimum G. extract improves the energy balance between the rate of caloric consumption and expenditure in rats. These features showed the health beneficial effect of PREOG over CP toxicity in rats.

\section{Conclusion}

In conclusion, the results from the present findings showed that polyphenol-rich extract of Ocimum gratissimum prevented adverse side effects of $\mathrm{CP}$ on the renal function via decreasing oxidative stress, prevented overproduction of pro-inflammatory cytokines and leukocytes infiltration, and improvement of antioxidant enzymatic activity of the renal tissues. Moreover, it was confirmed that CP induced reduction in aldosterone secretion, and facilitated excessive sodium and water loss through urine in the rats. However, extract of Ocimum G. improved renal function, increased aldosterone production, and prevented excessive sodium and water loss in $\mathrm{CP}$-treated rats. The presence of polyphenol and antioxidants in the leaves of Ocimum gratissimum make it a perfect candidate for the treatment and/or prevention of the nephrotoxic effect of cyclophosphamide. 


\section{Abbreviations}

Ocimum G.: Ocimum gratissimum; CP: Cyclophosphamide; PREOG: Polyphenol rich extract of Ocimum gratissimum; GC - MS: Gas chromatography-mass spectrometry; CRP: C-reactive protein; MPO: Myeloperoxidase; IL-6: Interleukin-6; MDA: Malondialdehyde; SOD: Superoxide dismutase; CAT: Catalase; LPO: Lipid peroxidation; GSH: Reduced glutathione; $\mathrm{H}_{2} \mathrm{O}_{2}$ : Superoxide radical; $\mathrm{ROS}$ : Reactive oxygen species; PAS: Periodic acid-Schiff.

\section{Acknowledgements}

Not applicable.

\section{Authors' contributions}

QKA made major contributions to the idea, design, investigation, acquisition and interpretation of data and writing of the manuscript. ROA made an important contribution in revising the manuscript for intellectual content. JGO made an important contribution in revising the manuscript for intellectual content. AA made an important contribution in revising the manuscript for intellectual content. MSI made an important contribution in revising the manuscript for intellectual content. OOK made an important contribution in revising the manuscript for intellectual content. DKA made an important contribution in revising the manuscript for intellectual content. All authors read and approved the final manuscript.

\section{Funding}

The research was solely funded by the authors.

\section{Availability of data and materials}

The datasets used and/or analyzed during the current study available from the corresponding author on reasonable request.

\section{Declarations}

\section{Ethics approval and consent to participate}

This study was approved by the Health Research Ethics Committee (HREC), Institutes of Public Health, Obafemi Awolowo University, Ile-lfe, Osun State, Nigeria and the study has been described in accordance with the ARRIVE guidelines [37] as well as National Academy of Sciences Guide for the Care and Use of Laboratory Animals [64].

\section{Consent for publication}

Not applicable.

\section{Competing interests}

The authors of this manuscript declare no conflict of interest.

\section{Author details}

${ }^{1}$ Department of Physiology, Faculty of Basic Medical Sciences, Adeleke University, Ede, Osun State, Nigeria. ${ }^{2}$ Department of Physiological Sciences, Faculty of Basic Medical Sciences, Obafemi Awolowo University, Ile-Ife, Osun State, Nigeria. ${ }^{3}$ Department of Physiology, Faculty of Basic Medical Sciences, Afe Babalola University, Ado-Ekiti, Ekiti State, Nigeria. ${ }^{4}$ Department of Anatomy and Cell Biology, Faculty of Basic Medical Sciences, Obafemi Awolowo University, Ile-Ife, Osun State, Nigeria. ${ }^{5}$ Department of Public Health, Faculty of Basic Medical Sciences, Adeleke University, Ede, Osun State, Nigeria. ${ }^{6}$ Department of Biochemistry, Faculty of Basic Medical Sciences, University of Medical Sciences, Ondo, Ondo State, Nigeria.

Received: 30 April 2021 Accepted: 19 October 2021

Published online: 02 November 2021

\section{References}

1. Chabner BA, Ryand DP, Pax-Ares L, Garcis-Carbonero, Calaresi P. Antineoplastic agents. In: Harnam JG, Libmirde LE, editors. Goodman and Gilman's the pharmacological basis of therapeutics. 10th ed. NewYork: McGraw Hill; 2001. p. 1389-459.
2. Chabner BA, et al. Antineoplastic agents. In: Brunton LL, Lazo JS, Parker KL, editors. Goodman and Gilman's the pharmacological basis of therapeutics. 11th ed. NewYork: McGraw Hill; 2006. p. 1322-8. 1694.

3. Ge B, Yang D, Wu X, Zhu J, Wei W, Yang B. Cytoprotective effects of glycyrrhetinic acid liposome against cyclophosphamide-induced cystitis through inhibiting inflammatory stress. Int Immunopharmacol. 2018;54:139-44.

4. Sinanoglu O, Yener AN, Ekici S, Midi A, Aksungar FB. The protective effects of spirulina in cyclophosphamide induced nephrotoxicity and urotoxicity in rats. Basic Transl Sci. 2012. https://doi.org/10.1016/j.urology.2012.06. 053.

5. Caglayan C, Temel Y, Kandemir FM, Yildirim S, Kucukler S. Naringin protects against cyclophosphamide-induced hepatotoxicity and nephrotoxicity through modulation of oxidative stress, inflammation, apoptosis, autophagy, and DNA damage. Environ Sci Pollut Res Int. 2018;25(21):20968-84.

6. Zhang J, Tian Q, Yung S, Chuen S, Zhou S, Duan W, et al. Metabolism and transport of oxazaphosphorines and the clinical implications. Drug Metab Rev. 2005;37:611-703.

7. Famurewa AC, Edeogu CO, Offor FI, Besong EE, Akunna GG, Maduagwuna EK. Downregulation of redox imbalance and iNOS/NF-KB/caspase-3 signalling with zinc supplementation prevents urotoxicity of cyclophosphamide-induced hemorrhagic cystitis in rats. Life Sci. 2021;266:118913.

8. Oyagbemi AA, Omobowale TO, Saba AB, Olowu ER, Dada RO, Akinrinde AS. Gallic acid ameliorates cyclophosphamide- induced neurotoxicity in wistar rats through free radical scavenging activity and improvement in antioxidant defense system. J Diet Suppl. 2016;13:402-19.

9. Abraham P, Isaac B. The effects of oral glutamine on cyclophosphamideinduced nephrotoxicity in rats. Hum Exp Toxicol. 2010;30(7):616-23.

10. Sherif 10 . Uroprotective mechanism of quercetin against cyclophosphamideinduced urotoxicity: effect on oxidative stress and inflammatory markers. J Cell Biochem. 2018;119(9):7441-8.

11. Omole JG, et al. Protective effect of kolaviron on cyclophosphamideinduced cardiac toxicity in rats. J Evid Based Integr Med. 2018;23:1-11. https://doi.org/10.1177/2156587218757649.

12. Effraim KD, Jacks TW, Sodipo OA. Histopathological studies on the toxicity of Ocimum gratissimum leave extract on some organs of rabbit. Afr J Biomed Res. 2003;6:21-5.

13. Akinmoladun AC, Ibukun EO, Emmanuel A, Obuotor EM, Farombi EO. Phytochemical constituent and antioxidant activity of extract from the leaves of Ocimum gratissimum. Sci Res Essays. 2007;2:163-6.

14. Alabi QK, Akomolafe RO, Omole JG, Adefisayo MA, Ogundipe OL, Aturamu A, et al. Polyphenol rich extract of Ocimum gratissimum leaves ameliorates colitis via attenuating colonic mucosa injury and regulating pro-inflammatory cytokines production and oxidative stress in rats. Biomed Pharmacother. 2018;103:812-22.

15. Offiah VN, Chikwendu UA. Antidiarrhoeal effects of Ocimum gratissimum leaf extract in experimental animals. J Ethnopharmacol. 1999;68:327-30.

16. Ezekwesili CN, Obiorah KA, Ugwu OP. Evaluation of anti -diarrheal effect of Ocimum gratissimum crude extract on albino rats. Biokemistri. 2004;16:122-31.

17. Olamilosoye KP, Akomolafe RO, Akinsomisoye OS, Adefisayo MA, Alabi QK The aqueous extract of Ocimum gratissimum leaves ameliorates acetic acid-induced colitis via improving antioxidant status and hematological parameters in male Wistar rats. Egypt J Basic Appl Sci. 2018;5:220-7.

18. Ijeh II, Omodamiro OD, Nwanna IJ. Antimicrobial effects of aqueous and ethanolic fractions of two spices, Ocimum gratissimum and Xylopia aethiopica. Afr J Biotechnol. 2005;4:953-6.

19. Nweze El, Eze EE. Justification for the use of Ocimum gratissimum $L$ in herbal medicine and its interaction with disc antibiotics. BMC Complement Altern Med. 2009;9:32.

20. Shittu STT, Oyeyemi WA, Lasisi TJ, Shittu SA, Lawal TT, Olujobi ST. Aqueous leaf extract of Ocimum gratissimum improves hematological parameters in alloxan-induced diabetic rats via its antioxidant properties. Int J Appl Basic Med Res. 2016;6:96-100.

21. Adesina TD, Nwinyi OC, Olugbuyiro JA. Prevention of bacterial biofilms formation on urinary catheter by selected plant extracts. Pak J Biol Sci. 2015;18(2):67-73.

22. Igbinosa EO, Idemudia OG. Anti-vibrio potentials of acetone and aqueous leaf extracts of Ocimum gratissumum (Linn). Trop J Pharm Res. 2016;15(4):743-50. 
23. Keziah EA, Nukenine EN, Danga SP, Younoussa L, Esimone CO. Creams formulated with Ocimum gratissimum L. and Lantana camara L. crude extracts and fractions as mosquito repellents against Aedes aegypti $\mathrm{L}$. (Diptera: Culicidae). J Insect Sci. 2015;15(1):45.

24. Akinrinde AS, Oyagbemi AA, Omobowale TO, Asenuga ER, Ajibade TO. Alterations in blood pressure, antioxidant status and caspase 8 expression in cobalt chloride-induced cardio-renal dysfunction are reversed by Ocimum gratissimum and gallic acid in Wistar rats. J Trace Elem Med Biol. 2016:36:27-37.

25. Li PC, Chiu YW, Lin YM, et al. Herbal supplement ameliorates cardiac hypertrophy in rats with $\mathrm{CCl}$ (4)-induced liver cirrhosis. Evid Based Complement Alternat Med. 2012;2012:139045.

26. Chiu YW, Chao PY, Tsai CC, et al. Ocimum gratissimum is effective in prevention against liver fibrosis in vivo and in vitro. Am J Chin Med. 2014;42(4):833-52.

27. Ofem OE, Eno AE, Antai AB. Gastric acid anti-secretory, anti-ulcerogenic and mucogenic effects of aqueous leaves' extract of Ocimum gratissimum in rats. Niger J Physiol Sci. 2012;27(1):41-7.

28. Tshilanda DD, Onyamboko DN, Babady-Bila P, et al. Anti-sickling activity of ursolic acid isolated from the leaves of Ocimum gratissimum L. (Lamiaceae). Nat Prod Bioprospect. 2015;5(4):215-21.

29. Nangia-Makker $P$, Raz T, Tait $L$, et al. Ocimum gratissimum retards breast cancer growth and progression and is a natural inhibitor of matrix metalloproteases. Cancer Biol Ther. 2013;14(5):417-27.

30. Pandey H, Pandey P, Singh S, Gupta R, Banerjee S. Production of anti-cancer triterpene (betulinic acid) from callus cultures of different Ocimum species and its elicitation. Protoplasma. 2015;252(2):647-55.

31. Pereira SL, de Oliveira JW, Angelo KK, da Costa AM, Costa F. Clinical effect of a mouth rinse containing Ocimum gratissimum on plaque and gingivitis control. J Contemp Dent Pract. 2011;12(5):350-5.

32. Singh $\mathrm{P}$, Jayaramaiah $\mathrm{RH}$, Agawane $\mathrm{SB}$, et al. Potential dual role of eugenol in inhibiting advanced glycation end products in diabetes: proteomic and mechanistic insights. Sci Rep. 2016;6:18798.

33. Pires AF, Madeira SV, Soares PM, et al. The role of endothelium in the vasorelaxant effects of the essential oil of Ocimum gratissimum in aorta and mesenteric vascular bed of rats. Can J Physiol Pharmacol. 2012;90(10):1380-5.

34. Kavaz D, Idris M, Onyebuchi C. Physiochemical characterization, antioxidative, anticancer cells proliferation and food pathogens antibacterial activity of chitosan nanoparticles loaded with Cyperus articulatus rhizome essential oils. Int J Biol Macromol. 2019;123:837-45.

35. Gulcin I, Oktay M, Kirecci E, Kufrevioglu OI. Screening of antioxidant and antimicrobial activities of anise (Pimpinella anisum L.) seed extracts. Food Chem. 2003;83:371-82.

36. Rakmai J, Cheirsilp B, Mejuto J, Torrado-Agrasar A, Simal-Gándara J. Physico-chemical characterization and evaluation of bio-efcacies of black pepper essential oil encapsulated in hydroxypropyl-beta-cyclodextrin. Food Hydrocoll. 2017;65:157-64.

37. Kilkenny C, Browne WJ, Cuthill IC, Emerson M, Altman DG. Improving bioscience research reporting the ARRIVE guidelines for reporting animal research. PLoS Biol. 2010;8(6):e1000412.

38. Misra HP, Fridovich I. The role of superoxide anion in the autooxidation of epinephrine and a simple assay for superoxide dismutase. J Biol Chem. 1972;247:3170-5.

39. Aebi H. Catalase. Methods Enzymol. 1984;105:121-6.

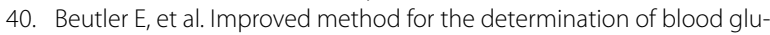
tathione. J Lab Clin Med. 1963;51:882-8.

41. Wolff SP. Ferrous ion oxidation in the presence of ferric ion indicator xylenol orange for measurement of hydroperoxides. Methods Enzymol. 1994;233:182-9.

42. Ohkawa $\mathrm{H}$, et al. Assay for lipid peroxide in animal tissues by thiobarbutiric acid reaction. Anal Biochem. 1979;95:351-8.

43. Xia Y, Zweier JL. Measurement of myeloperoxidase in leukocyte-containing tissues. Anal Biochem. 1997;245:93-6.

44. Alabi QK, Akomolafe RO, Olukiran OS, Nafiu AO, Adefisayo MA, Owotomo $\mathrm{Ol}$, et al. Combined administration of I-carnitine and ascorbic acid ameliorates cisplatin-induced nephrotoxicity in rats. J Am Coll Nutr. 2018;37(5):387-98.

45. Kern JC, Kehrer JP. Acrolein-induced cell death: a caspaseinfluenced decision between apoptosis and oncosis/necrosis. Chem Biol Interact. 2002;139:79-95.
46. Idris AO, Alabi QK, Ologe FM, Oluogun WA, Akanbi MHJ, Iwalewac EO. Evaluation of acrylamide exposure in pregnant wistar rats as a risk of developing renal disease in their litters. Environ Sci Pollut Res. 2021. https://doi.org/10.1007/s11356-021-13580-8.

47. Nafees S, Rashid S, Ali N, Hasan SK, Sultana S. Rutin ameliorates cyclophosphamide induced oxidative stress and inflammation in Wistar rats: role of NFKB/MAPK pathway. Chem Biol Interact. 2015;231:98-107.

48. Bray C, Bell LN, Liang H, Haykal R, Kaiksow F, Mazza JJ, et al. Erythrocyte sedimentation rate and $\mathrm{C}$-reactive protein measurements and their relevance in clinical medicine. WMJ. 2016;115(6):317-21.

49. Klebanoff SJ. Myeloperoxidase: friend and foe. J Leukoc Biol. 2005;77(5):598-625.

50. Mantovani A, Muzio M, Garlanda C, Sozzani S, Allavena P. Macrophage control of inflammation: negative pathways of regulation of inflammatory cytokines. Novartis Found Symp. 2001;234:120-31.

51. Omole JG, Alabi QK, Aturamu A, Adefisayo MA, Oluwayomi O, Dada MB, et al. Barium chloride dose-dependently induced heart and lung injury in Wistar rats. Environ Toxicol. 2019;34(12):1303-12.

52. Alabi QK, et al. Kolaviron attenuates diclofenac-induced nephrotoxicity in male Wistar rats. Appl Physiol Nutr Metab. 2018;43:956-68.

53. Song S, Meyer M, Turk TR, Wilde B, Feldkamp T, Assert R, et al. Serum cystatin $C$ in mouse models: a reliable and precise marker for renal function and superior to serum creatinine. Nephrol Dial Transplant. 2009;24:1157-61.

54. Ogundipe DJ, Akomolafe RO, Sanusi AA, Imafidon CE, Olukiran OS, Oladele AA. Ocimum gratissimum ameliorates gentamicin-induced kidney injury but decreases creatinine clearance following sub-chronic administration in rats. J Evid Based Complementary Altern Med. 2017;22(4):592-602

55. Ritz E. Albuminuria and vascular damage - the vicious twins. N Engl J Med. 2003:348:2349-52.

56. Stehouwer CD, Smulders YM. Microalbuminuria and risk for cardiovascular disease: analysis of potential mechanisms. J Am Soc Nephrol. 2006;17(8):2106-11.

57. Ranchoux B, Günther S, Quarck R, et al. Chemotherapy induced pulmonary hypertension: role of alkylating agents. Am J Pathol. 2015;185(2):356-71.

58. Mikaelian I, Buness A, de Vera-Mudry MC, et al. Primary endothelial damage is the mechanism of cardiotoxicity of tubulin-binding drugs. Toxicol Sci. 2010;117(1):144-51.

59. Bressler RB, Huston DP. Water intoxication following moderate-dose intravenous cyclophosphamide. Arch Intern Med. 1985;145(3):548-9.

60. Salido M, Macarron P, Hernandez-Garcia C, D'Cruz DP, Khamashta MA, Hughes GR. Water intoxication induced by low-dose cyclophosphamide in two patients with systemic lupus erythematosus. Lupus. 2003;12(8):636-9.

61. Nafiu AO, Akomolafe RO, Alabi QK, Idowu CO, Odujoko OO. Effect of fatty acids from ethanol extract of Moringa oleifera seeds on kidney function impairment and oxidative stress induced by gentamicin in rats. Biomed Pharmacother. 2019;117:109154.

62. Singh G, Fries JF, Williams CA, Zatarain E, Spitz P, Bloch DA. Toxicity profiles of disease modifying antirheumatic drugs in rheumatoid arthritis. J Rheumatol. 1996;18(2):188-94.

63. Ogundipe DJ, Akomolafe RO, Sanusi AA, Imafidon CE, Olukiran OS, Oladele AA. Effects of two weeks administration of Ocimum gratissimum leaf on feeding pattern and markers of renal function in rats treated with gentamicin. Egypt J Basic Appl Sci. 2016;3(3):219-31.

64. National Research Council (US) Committee for the Update of the Guide for the Care and Use of Laboratory Animals. Guide for the Care and Use of Laboratory Animals. 8th edition. Washington (DC): National Academies Press (US); 2011.

\section{Publisher's Note}

Springer Nature remains neutral with regard to jurisdictional claims in published maps and institutional affiliations. 